This is the accepted version of the article published by Springer in Journal of Regulatory Economics. Published version available from: https://doi.org/10.1007/s11149-017-9341-y

Accepted version downloaded from SOAS Research Online: http://eprints.soas.ac.uk/24624/

\title{
DISCRETIONARY ENFORCEMENT AND STRATEGIC INTERACTIONS BETWEEN ENFORCEMENT AGENCIES AND FIRMS: A THEORETICAL AND LABORATORY INVESTIGATION
}

\author{
A.R. Germani, ${ }^{1}$ A. Morone, ${ }^{2}$ P. Morone, ${ }^{3}$ P. SCARAmozzino ${ }^{4}$
}

SEPTEMBER 2017

ABSTRACT. This paper presents a game theoretic morphological analysis of the strategic interactions between environmental enforcement authorities and polluting firms. The models explore the role of discretion that such authorities enjoy, either in deciding how to pursue environmental violations (investigative and prosecutorial discretion) or in judging them (judicial discretion). The purpose is to identify both the optimal firms' behaviour in terms of compliance, and the enforcement authorities' optimal strategies in terms of enforcement actions to undertake. Consistent with the setting of the game theoretic models, the role of the enforcement agencies in deterring firms from polluting is, then, empirically tested by means of laboratory experiments. Laboratory evidence on compliance behaviour of firms when faced with enforcement conditions predicted by the theoretical models set up is discussed for the different experimental treatments performed. Overall, we suggest that making environmental enforcement less predictable for the firms, and thus creating a degree of uncertainty for the violators, can actually encourage deterrence and, thus, improve compliance. Thus, a partly unpredictable enforcement strategy may generate more compliance than an environmental policy that is known with certainty in advance.

JEL classification: 017; 004; 001.

Keywords: environmental enforcement, discretion, game theory, experimental economics.

\footnotetext{
${ }^{1}$ University of Rome "Sapienza" (Italy).

${ }^{2}$ University of Bari “Aldo Moro” (Italy), and University Jaume I (Spain).

${ }^{3}$ University of Rome "Sapienza" (Italy).

${ }^{4}$ SOAS University of London (U.K.) and University of Rome "Tor Vergata" (Italy).
} 
This is the accepted version of the article published by Springer in Journal of Regulatory Economics. Published version available

from: https://doi.org/10.1007/s11149-017-9341-y

Accepted version downloaded from SOAS Research Online: http://eprints.soas.ac.uk/24624/

\section{INTRODUCTION}

At the centre of the longstanding debates in environmental economics and, at the same time, one of the main concerns for governments and policy makers is the adoption of the best environmental policies able to increase the rate of compliance and the overall level of enforcement. With an increase in both actual environmental problems and awareness of harms stemming from them, it seems likely that, not only in the front-runners States (i.e., Sweden, Norway and Denmark in the European Union) but also elsewhere at a global level, the criminalization of environmentally harmful activities will continue to expand. There is no doubt that enforcement plays a central role in the administration of any regulatory and normative prescription and this is particularly true for environmental laws, for which, often, the lack of inspections and effective monitoring make them a sort of non-binding guidance (Shimshack 2014). An important feature of the enforcement of environmental laws is that some violators are sentenced at criminal level while others, who have in substance committed the same crime, are not punished or are sanctioned with a purely administrative or civil fine. It has been demonstrated (Cory and Germani 2002; Babbit, Cory, et. al. 2004) that for similar violations to the U.S. Clean Water Act, seemingly similar defendants may receive very disparate sentences; these inconsistencies can be seen as running the risk of creating serious social and economic policy distortions, either toward an over-criminalization attitude or in favour of a more lenient approach, by creating respectively over-deterrence or under-deterrence.

One of the main tasks of enforcement agencies is to determine which violators to prosecute, and whether to pursue violations at the administrative, civil or criminal levels; for instance, the major U.S. environmental statutes, together with the Federal Sentencing Guidelines, ${ }^{5}$ afford substantial discretion to the Environmental Protection Agency (EPA - the entity that the U.S. government charged with enforcing the nation's environmental laws), the Department of Justice (DOJ), and the courts: they can be more aggressive or more accommodating on environmental violations and can carry out a weaker or a stronger enforcement. The possibility that environmental regulations might be enforced selectively or arbitrarily, in turn, raises the issue of potentially inadequate enforcement due to the regulatory competition that may occur between the enforcement agencies (Yeager 1991).

Inspired by these stylized facts, we investigate the relationships between enforcement agencies that have traditionally been treated as independent of each other, in a strategic game together with firms. Even though unpredictable and contradictory enforcement can create uncertainty and adverse effects that could potentially limit the effectiveness of environmental policies, we provide a possible rationale for these apparent incongruities. The unpredictability of the enforcement strategy need not be meant as a literal randomization of the strategy of the environmental authorities: rather, it can be seen as reflecting the heterogeneity of views within each one of the environmental agencies. In 1973, Harsanyi presented the so-called "purification" interpretation of mixed strategy Nash equilibrium: the idea is that players play pure strategies but by introducing some kind of heterogeneity in the game (generated, for example, by incomplete information or random matching), a player is no longer sure that his/her opponent is choosing the same action, having only a diffuse belief over his/her opponent's moves. In Harsanyi's interpretation, a mixed strategy represents uncertainty for a player on how the other players will choose their strategies, rather than deliberate randomization (Morris 2008). Randomization can therefore be rationalized in terms of the impossibility by the firms to predict in advance according to which views their

\footnotetext{
${ }^{5}$ In 1984, the U.S. Congress passed the Sentencing Reform Act (SRA) that completely transformed the traditional sentencing process in an attempt to reduce unwarranted disparity in sentencing, to ensure certainty, proportionality and uniformity of punishment, and to establish more serious penalties for specific categories of offenses. In order to achieve these goals, Congress created the United States Sentencing Commission as an independent, permanent agency in the judicial branch with the main purpose to develop an unprecedented body of laws to regulate federal sentencing: the Federal Sentencing Guidelines. The Sentencing Guidelines went into effect in November 1987, and apply to all federal crimes committed on or after that date.
} 
This is the accepted version of the article published by Springer in Journal of Regulatory Economics. Published version available from: https://doi.org/10.1007/s11149-017-9341-y

Accepted version downloaded from SOAS Research Online: http://eprints.soas.ac.uk/24624/

case will be considered.

Overall, besides suggesting that a discretionary enforcement may generate higher compliance levels (Baker et al. 2004), and contrary to the prevailing consensus in the literature (Sunstein et al. 2002) which believes that a consistent and predictable enforcement is preferable, we also found that criminal enforcement can enhance deterrence by improving firms' compliance. This result emerges from the strategic interaction assumed between the EPA and the DOJ showing that they not only influence each other in their enforcement decisions, but they also impact on the firms' decisions increasing (under certain circumstances) their probability of compliance. In fact, while the enforcement relationship between enforcement authority and firm has been widely modelled as an inspection game (played by a person who violates the law and the inspector), our original results and contribution centre around the question on how EPA, DOJ and firms, given their respective objective functions, can interplay together, assuming that the enforcement agencies act as centralized agents. ${ }^{6}$

Our models draw upon the U.S. environmental institutional structure, where monitoring and enforcement occur in a decentralized setting with federal oversight (Gray and Shimshack 2011) outlining i) the main actions of regulatory agency and courts to bring a firm into compliance and ii) the responses to these actions by the regulated firms. In Europe, by contrast, in environmental matters, there is no comparable European-level regulatory agency, where enforcement of environmental laws is in the hands of domestic, rather than centralized European enforcement authorities (Faure, Johnston 2008). The European Environmental Agency (EEA) has no enforcement authority (Krämer 2002); the rules are set at the European level and their implementation and enforcement are entirely left to the Member States. EU institutions themselves face considerable obstacles when even attempting to monitor compliance with EU requirements in any individual country (Clifford 2007).

The paper is organized as follows. Section 2 reviews the relevant literature directly related to this issue. Section 3 presents the game theory models on enforcement and discretion. Section 4 presents the experimental design. Section 5 analyses the experimental results and section 6 offers some concluding remarks.

\section{RELATED LITERATURE}

This paper builds on existing studies on optimal levels of monitoring and sanctions (Cohen 1999; Polinsky and Shavell 2000; Heyes 2000; Deily and Gray 2007; Gray and Shimshack 2011; Mintz 2012; Stranlund 2013), on the fundamental problem - which is well recognized and discussed in the literature - that enforcement efforts are not exogenous but typically are an endogenous response by the enforcement agency to the perceived compliance behaviour of the firms (Harrington 1988; Helland 1998; Gray and Shimshack 2011; Kleven et al. 2011) and on the notions of selective enforcement (Harrington 1988; Friesen 2003; Lando and Shavell 2004) and regulatory dealing (Heyes 1998; Heyes and Rickman 1999).

Closely related works are also those by Tsebelis (1989), Holler (1993) and Franckx (2001a,b; 2002). In Tsebelis, individuals' offending behaviour is modelled as a one-shot 2-by-2 game between public and police; the game does not have a pure strategy equilibrium, instead it has a unique mixed strategy equilibrium. Holler analyses a 2-by-2 game played between a polluter and the "police," in which the payoffs of the two players can be manipulated by an exogenous third player called the policy-maker, who is assumed to be interested in reducing pollution; however, Holler does not

\footnotetext{
${ }^{6}$ It should be noted that in some jurisdictions, the enforcement agency is fragmented (as in Italy and Belgium, in Europe) with regard to investigation and monitoring (Svatikova 2011) and the incentives of the delegated or decentralized agents might differ from those of the central agency (Linder and McBride 1984).
} 
This is the accepted version of the article published by Springer in Journal of Regulatory Economics. Published version available from: https://doi.org/10.1007/s11149-017-9341-y

Accepted version downloaded from SOAS Research Online: http://eprints.soas.ac.uk/24624/

explicitly define the agents' payoff functions. ${ }^{7}$ Franckx (2001a), in a repeated games setting, found that if the inspection agency can commit itself to a permanent observation of ambient pollution by one single firm, it can obtain partial compliance without ever penalizing the polluter, emphasizing that ambient inspections can create a potentially interesting link between the enforcement agency and the polluter when they interact, in repeated games, on long-run relationship. If the noncompliant firm is brought to the court it will always be convicted; however, the type of measure that the court will take against the polluter is not taken into consideration. In Franckx (2001b), inspection games between polluting firms and an inspection agency are considered to identify under which conditions ambient inspections can improve compliance. In Franckx (2002) the main point of the analysis is that environmental inspections create strategic interactions between polluters: in equilibrium, the probability of inspection also depends on the probability of compliance of other polluters. In another game theoretic framework by Scholz (1991) the enforcement agency's approach depends on where the agency and firm are in the enforcement process, involving the regulator and the firm in an on-going series of prisoner's dilemma games. Because the regulatory game is played repeatedly, the regulator chooses its action based on the firm's behaviour in the previous rounds. If the firm had cooperated, the agency should cooperate, but if the firm defected the agency should punish it until the firm again adopts a co-operative behaviour. Our work relates to these papers, since the adoption of randomized strategies can be interpreted as the exercise of discretion, but our approach differs from previous research on enforcement in that it considers the interactions among the different players involved, namely regulatory agency and criminal law authority, in a strategic enforcement game. Compared to the extensive theoretical literature on the monitoring and enforcement aspects of environmental regulation (Cohen 1999; Polinsky and Shavell 2000; Stafford 2002; Shimshack and Ward 2005; Glicksman and Earnhart 2007), the empirical literature is still lagging behind. In particular, relatively little is known about why firms decide whether to comply or not with environmental regulations, partly because comprehensive data on compliance and enforcement have been difficult to obtain (Cohen 2000), but also because there is a lack of empirical data on the motivations influencing firms' compliance behaviour. However, most of the empirical research looks at the factors that can influence the inspection decisions of environmental agencies - some examples are Magat and Viscusi (1990), Laplante and Rilstone (1996), Dion et al. (1998), Helland (1998), Dasgupta et al. (2000), Stafford (2003), Anderson and Stafford (2003), Rousseau (2007) - where it is extensively shown that increases in the frequency of inspections in regulated facilities increase compliance.

The law and economics literature has extensively discussed not only the use of criminal as opposed to administrative law in general, as well as how this applies to the enforcement of environmental law specifically (Faure and Svatikova 2012; Bowles et al. 2008; Polinsky and Shavell, 2000; Ogus 2004; Ogus and Abbot 2002; Rasmusen, 1996; Shavell 1993) but it has also vastly investigated the effectiveness of enforcement policies and the imposition of sanctions (for a review see Blondiau, Billiet, Rousseau 2015). Based on this literature, enforcement through criminal law is preferred in presence of i) large scale damages to society, ii) socially unacceptable offender's behavior, iii) low detection probabilities, iv) judgment-proof defendant, v) need to generate additional stigma and/or an educative role. On the other hand, the literature points to the fact that, due to the high enforcement costs of the criminal system, administrative sanctions might be preferred in presence of i) low scale damages, ii) over-deterrence and of iii) inadequate information of the offender.

Even though administrative sanctions are almost identical to criminal sanctions with respect to their goals of

\footnotetext{
${ }^{7}$ Holler's (1993) assumptions with respect to the payoffs are the followings: assumption 1) if the agency inspects the polluter, the polluter prefers to comply; assumption 2) if the agency does not inspect the polluter, the polluter prefers not to comply; assumption 3) if the polluter does not comply, the agency prefers to inspect the polluter; assumption 4) if the polluter complies, the agency prefers not to inspect the polluter.
} 
This is the accepted version of the article published by Springer in Journal of Regulatory Economics. Published version available from: https://doi.org/10.1007/s11149-017-9341-y

Accepted version downloaded from SOAS Research Online: http://eprints.soas.ac.uk/24624/

deterrence and punishment, they have procedural differences, which can be economically relevant. The main difference between administrative and criminal sanctions is that the former are easier to administer and less costly to impose than the latter because of the more complicated criminal procedure (Faure and Svatikova 2012; Faure et al. 2009). The concept of the enforcement pyramid (Ayres and Braithwaite 1992) can be considered a normative benchmark and it shows that enforcement strategies escalate from lenient approaches at the bottom to more severe enforcement strategies with sanction-based approaches like the revocation of licenses and the application of jail time sentences at the top of the enforcement pyramid. The pyramid consists of a base level where a large number of relatively minor violations is handled through administrative actions, followed by an intermediate level where a smaller number of more serious violations is handled through civil actions and, finally, a superior and last level where a small number of very serious violations is handled through criminal prosecutions.

In Europe, while the more recent EU official policy encourages the use of criminal enforcement and aims at strengthening enforcement systems that rely strongly on administrative enforcement (European Commission 2008), several European countries that predominantly relied on criminal enforcement (Hampton 2005; Macrory 2006) in the past (i.e., Belgium and UK) recently moved towards more administrative enforcement (Svatikova 2012). These emerging developments are moving Europe towards combined criminal-administrative enforcement systems (Billiet 2012).

Our results strengthen, to some extent, this approach showing that a combined criminal-administrative enforcement could have positive effects on compliance. Introducing the criminal enforcement leads to higher deterrence not only because of higher expected penalties but also because, in the interplay with the regulatory agency, this latter would have a greater incentive to inspect. So in terms of deterrence, the hypothesized effect of introducing a criminal enforcement system can be summarized as follows: under the assumed circumstance that the DOJ can have a greater incentive to prosecute civilly (because it is less resource intensive) than criminally, the probability that the EPA inspects and punishes the violator increases, thus the probability of compliance for potential offenders increases and this leads to a lower number of environmental offenses. Our analysis brings new evidence in the realm of enforcement and discretion studies since, to the best of our knowledge, it is the first attempt to offer a theoretical analysis and an experimental validation on the strategic interactions between enforcement agencies and the firms combining the use of administrative and civil/criminal enforcement approaches.

\section{THE Enforcement GaMe Models}

The toolbox employed by the EPA to achieve and maintain compliance includes monitoring, investigation, administrative (i.e., suspension or revocation of licenses) and judicial (civil and criminal) actions, penalties, compliance assistance and incentive approaches (Abbot 2009; Gray and Shimshack 2011; Tosun 2012). Most compliance violations are resolved administratively by the states and EPA (Esworthy, 2014). ${ }^{8}$ Civil judicial actions, which may be filed by states or EPA, are the next most frequent enforcement action; EPA may refer civil cases to the U.S. DOJ ${ }^{9}$ that, in coordination with EPA criminal investigators, may prosecute criminal violations against individuals or entities who knowingly disregard environmental laws or are criminally negligent. ${ }^{10}$

\footnotetext{
${ }^{8}$ EPA (2016) concluded 1,360 administrative penalty orders complaints in FY2016, https://www.epa.gov/enforcement/enforcement-annual-results-numbers-glance-fiscal-year-2016

${ }^{9}$ EPA referred 152 civil cases in FY2016 (EPA, 2016).

${ }^{10}$ EPA reported the assessment of nearly $\$ 5.8$ billion in civil penalties (administrative and judicial) and more than $\$ 207$ billion in combined criminal fines, restitution, and court-ordered environmental projects during FY2016. Criminal fines and restitution punish misconduct, deter other violators and, along with court- ordered environmental projects, help to
} 
This is the accepted version of the article published by Springer in Journal of Regulatory Economics. Published version available from: https://doi.org/10.1007/s11149-017-9341-y

Accepted version downloaded from SOAS Research Online: http://eprints.soas.ac.uk/24624/

Since the literature primarily studies U.S. institutions, we focus here on the EPA and the DOJ in the U.S. regulatory setting. ${ }^{11}$ Enforcement of federal environmental laws in the U.S. occurs within a complex and dynamic statutory framework and organizational setting (Esworthy 2014), it can vary from statute to statute and it can be driven by specific circumstances associated with a particular type of pollution (i.e., water discharges, hazardous wastes, etc.); given these many factors, it is difficult to generalize about environmental enforcement. However, for several federal environmental laws (Clean Air Act, Clean Water Act, Comprehensive Environmental Response, Compensation, and Liability Act), the EPA is the primary federal implementing agency and its actions often require coordination with other federal agencies, most frequently DOJ. This study, therefore, is intended to provide a broad perspective on the primary key players responsible for correcting violations and inducing compliance, highlighting the general context within which a range of enforcement actions may take place.

The functioning of the criminal justice system is an essential determinant of any policy outcomes (Polinsky and Shavell 2006) that has been attracting the attention of scholars at least since Becker and Stigler (1974). In the United States, the national court system handles all criminal cases and those civil enforcement cases that are not handled administratively or by States. To assist the national judges, the U.S. government has developed environmental units of trial attorneys who are experts in environmental offenses, both criminal and civil. They receive cases investigated by EPA inspectors and police and assist national prosecutors located in district offices throughout the United States to present and prosecute the cases (UNEP 2006). When US EPA enforcement authorities determine that administrative courts are inappropriate or ineffective, the case is referred to DOJ's environmental trial attorneys for resolution in the national court system (Hertz 2011). In the U.S criminal justice system, the prosecutor occupies a powerful position due to the fact that he can decide whether and what charge to file, what penalty to seek and whether to prosecute minor offenses or unpopular laws (Kane 1993). This discretion allows some sort of bias influencing a prosecutor's decision whether to prosecute and whether to pursue a conviction or non-criminal sanctions (Frase 1980). The examination of all the above-mentioned aspects requires one to consider one of the most difficult realities in the U.S. enforcement of environmental laws, that is the interaction between the EPA and the Department of Justice, investigating to what extent the objectives of these offices can be coordinated to promote environmental compliance.

The economic structure of the enforcement problem is analysed throughout the development of game theoretic models, in which the violator's behaviour is influenced by the course of actions discretionally implemented by the enforcement agencies' actions. Model I is the baseline model where the firm plays against the EPA; Model II is a heterogeneous model where the firm plays against two enforcement agencies, under the assumption that their respective objective functions are different (note that model I is a sub-game of model II).

Regarding the objective functions of regulatory agency, in the literature, there is no consensus on their specification (Cohen 1999), ranging from minimization of non-compliance to maximization of social welfare, from minimization of agency budgets constraints to maximization of agency political support (Niskanen 1975; Peltzman 1976; Viscusi and Zeckhauser 1979; Harrington 1988; Jones and Scotchmer 1990; Heyes and Rickman 1999). According to Firestone (2003), the EPA does not pursue all enforcement cases administratively and to explain why and how EPA makes its decisions, Firestone explored the implications of five main theoretical "alternative" motivations for EPA

remedy the harm caused by the criminal conduct. Criminal results, in recent years, have been dominated by two very large cases: BP Deepwater Horizon, resolved in 2013, and Duke Energy coal ash spill, resolved in 2015.

${ }^{11}$ For example, the U.S. Environmental Protection Agency (EPA) has a comprehensive regulatory and enforcement role and can impose penalties up to $\$ 10,000$ per day, within a maximum of $\$ 125,000$ on anyone discharging pollutants into a river in violation of the Clean Water Act (CWA). ${ }^{11}$ In turn, these regulatory violations are also held criminal offences, and consequently subject to criminal punishment (fines or imprisonment) decided and enforced by the courts. 
This is the accepted version of the article published by Springer in Journal of Regulatory Economics. Published version available from: https://doi.org/10.1007/s11149-017-9341-y

Accepted version downloaded from SOAS Research Online: http://eprints.soas.ac.uk/24624/

enforcement decisions: (i) social welfare maximization; (ii) violation minimization; (iii) case maximization; (iv) environmental harm minimization; and (v) political support maximization. ${ }^{12}$ Overall, the objectives of maximizing social welfare and minimizing environmental harm appear to be the main motivations for EPA, while there is little empirical support for the political maximization objective. In the literature, however, there has been widespread support for introducing a certain degree of differentiation between the regulatory agency and the justice authority (Stigler 1971; Niskanen 1975; Peltzman 1976; Yeager 1991; DiMento 1993; Posner 1993; Glaeser et al. 2000; Barker 2002; Rasmusen et al. 2009; Blondiau and Rousseau, 2010). Prosecutors may respond to incentive structures that favour pursuing cases other than environmental violations, while the EPA may wish to have more independence without coordination with the DOJ, or may not want to share merit for the case with the DOJ. This can also open up the problem of prosecutorial behaviour, which is extensively studied in the law and economics literature, especially with regard to career concerns underlying the importance of the incentives facing State and federal prosecutors. Posner (1993) was the first author to maintain that judges behave just like "ordinary people", in a rationality-based framework; since then, a significant body of theoretical research has been developed for understanding judicial behaviour at a trial. Rasmusen et al. (2009) focus on the problem of prosecutorial discretion in terms of case selection, i.e., whether to allocate resources broadly over many cases or intensively to a few cases. Forced by limitations of time and resources, prosecutors drop some cases, prosecute others, and prosecute some more intensely than others. They show that a prosecutor's high conviction rate may not be a sign that he/she is tough on crime; instead, he/she might just be taking on easy cases and letting too many criminals go without prosecuting them. Therefore, we assume that the EPA and the DOJ do not share the same objective functions given that their coordination can be exacerbated by a variety of goals: the DOJ alongside the minimization of environmental violations, might also take into account other factors, such as its own prestige, popularity/political reelection/reputational/career factors related to prosecutors' concerns.

\subsection{The Baseline Model: Interactions BetWeen the FirM AND THE EPA}

The interactions between the firm and the EPA are modelled as a coordination game and the basic structure of the game is close to those developed by Holler (1993) and by Franckx (2001a). The game tree corresponding to the extensive form of the game is illustrated in Figure 1 and the payoff matrix associated with the normal form of the game is given in Table 1.

\section{[FIGURE 1 ABOUT HERE]}

The firm can decide between complying with environmental regulations and not complying, by assessing the costs and benefits of compliance versus pollution. The EPA, not knowing the strategy chosen by the firm, must decide whether to carry out inspections or not. If the firm complies, it has to sustain a cost. This cost is not incurred if the firm decides not to comply. The EPA also has to incur a cost if it decides to carry out an inspection. If EPA carries out an inspection and the firm is not complying, EPA can levy a fine on the firm. However, if the EPA does not carry out an inspection and the firm does not comply, the EPA will internalize the cost of the environmental damage.

We denote by $v$ the value to the firm if it does not comply, by $c$ the cost of compliance to the firm, by $e$ the

\footnotetext{
${ }^{12}$ Firestone's (2003) main results are that when EPA seeks to i) maximize social welfare, ii) minimize the number of violations, or iii) maximize political benefits, it would find judicial remedies less attractive and thus increasingly will choose to handle violations administratively. Only when EPA seeks to minimize environmental harm, as the actual or potential for harm increases, it would invest greater financial resources to punish the conduct criminally.
} 
This is the accepted version of the article published by Springer in Journal of Regulatory Economics. Published version available from: https://doi.org/10.1007/s11149-017-9341-y

Accepted version downloaded from SOAS Research Online: http://eprints.soas.ac.uk/24624/

environmental damage that is generated if the firm does not comply and that would be internalised by EPA, by $i$ the cost of inspection, and finally by $f$ the fine that would be levied by EPA on the firm if the latter is found to be non-compliant. Both the legal standards and the fine for non-compliance are exogenous; we thus follow here the approach pioneered by Reinganum and Wilde (1986) in the context of tax auditing where, in practice, enforcement is delegated by the legislator to an agency which controls neither the standards nor the penalties (Franckx 2001a). The EPA internalizes the value of the fine since the latter can contribute positively to social welfare objectives. All the parameters of the model, including the compliance costs and the fines, are known to all players.

\section{[TABLE 1 ABOUT HERE]}

For simplicity, players are assumed to be risk neutral. All the above parameters are strictly positive. We assume that the following additional restrictions on parameter values hold:

$$
\begin{aligned}
& i<f \\
& c<f \leq \bar{f}
\end{aligned}
$$

Condition (1) states that the fine is larger than the cost of inspection and is required to rule out the trivial result that never to inspect is a dominant strategy for EPA. Allowing for a corner solution in which the EPA never inspects (when $i>f$ ) does not add substantive insight to the analysis. The first part of condition (2) requires that the value of the fine levied by the EPA is greater than the cost of compliance, and is required to rule out the trivial result that never to comply is a dominant strategy for the firm. The upper bound on the fine, $\bar{f}$, rules out the possibility that EPA may set its fine at an infinite value. $^{13}$

Figure 1 illustrates the strategic form of the game by showing the moves that the firm and EPA can make. It is immediate to verify that, if the firm knows that the EPA will carry out an inspection, it will be better off by complying, since its expected pay-off is $v-c$ if it complies and $v-f$ if it does not comply, with $v-f<v-c$ by assumption (2). On the other hand, if EPA decided not to carry out the inspection, the firm will be better off by not complying, since its expected payoff is $v$-c if it complies and $v$ if it does not comply, with $v>v$-c. Conversely, if the firm complies then the EPA would be better off by not carrying out the inspection. By contrast, if the firm does not comply, it would be preferable for the EPA to inspect.

Hence, the game has no Nash Equilibrium in pure strategies. There does exist, however, a mixed strategy Nash equilibrium where the firm and the EPA randomize their choice of action (Ordershook 1986). In a mixed-strategy Nash equilibrium, a player is indifferent between all of the available pure strategies with positive probabilities, but he/she randomizes so as to hide his/her intentions from the other players. ${ }^{14}$ According to the purification theorem of Harsanyi (1973), the firm and the EPA randomize their behaviours in the following way. Let us denote by $p$ the probability of compliance by the firm and by $q$ the probability of inspection by the EPA. The expected payoff to EPA if it carries out an inspection is given by:

$$
E\left(\pi_{E P A}^{I}\right)=p(-i)+(1-p)(-i-e+f)=-i-e+f+e p-f p
$$

The expected payoff to EPA if it does not carry out an inspection is:

\footnotetext{
${ }^{13}$ Some of the justifications for assuming an upper bound for the feasible fine are: i) financial constraints on the side of the firm lead to reasonable fines in order to avoid bankruptcy; ii) the "punishment fits the crime" principle (Michael 1992) requires that the severity of penalty for a wrongdoing should be reasonable and proportionate to the severity of the infraction and is another reason for assuming an upper bound on the feasible fine.

${ }^{14}$ This is a standard property of mixed-strategy Nash equilibrium, since the objective function is linear in the probability.
} 
This is the accepted version of the article published by Springer in Journal of Regulatory Economics. Published version available from: https://doi.org/10.1007/s11149-017-9341-y

Accepted version downloaded from SOAS Research Online: http://eprints.soas.ac.uk/24624/

$$
E\left(\pi_{E P A}^{N I}\right)=p(0)+(1-p)(-e)=e p-e
$$

The firm will choose the probability of compliance, $p$, in such a way that the EPA must be indifferent between inspecting or not. This requires that $E\left(\pi_{E P A}^{I}\right)=E\left(\pi_{E P A}^{N I}\right)$. Solving for $p$ yields:

$$
p=1-\frac{i}{f}
$$

Note that $p$ is a well-defined probability $(0<p<1)$ since $0<i<f$ by condition (1). The expected payoffs to the firm under compliance and non-compliance are respectively:

$$
\begin{aligned}
& E\left(\pi_{F}^{C}\right)=q(v-c)+(1-q)(v-c)=v-c \\
& E\left(\pi_{F}^{N C}\right)=q(v-f)+(1-q) v=v-q f
\end{aligned}
$$

The EPA will choose the probability of inspection $q$ in such a way that the firm is indifferent between complying or not: $E\left(\pi_{F}^{C}\right)=E\left(\pi_{F}^{N C}\right)$. Solving for $q$ yields:

$$
q=\frac{c}{f}
$$

Note that $q<1$ since $c<f$ by condition (2). The above results can be summarized by the following proposition.

Proposition 1. The game played by the firm and EPA has no pure strategy Nash Equilibrium. The mixed strategy Nash Equilibrium is characterized by the following randomized strategies:

(a) The firm complies with probability $p=1-i / f$;

(b) The EPA carries out an inspection with probability $q=c / f$.

The probability of compliance by the firm is a decreasing function of the cost of inspection and an increasing function of the fine. A larger penalty would have a deterrent effect and the firm would have a greater incentive to comply. On the other hand, if the cost of inspection increases, the probability of compliance decreases: given that inspections may induce firms to improve their environmental performance, if they perceive that inspection and monitoring costs are high for the environmental authority, they will tend to decrease their level of care thus reducing the level of compliance.

The probability of inspection by EPA is an increasing function of the cost of compliance by the firm. This implies that when compliance costs are higher and the firm would have greater incentive to violate, the probability of firm's inspection by EPA must increase accordingly. On the other hand, the probability of inspection is a decreasing function of the fine. This implies a trade-off between the fine and the probability of inspection: the greater the fine, the lower the probability of inspection. In other words, a greater fine, which would increase the costs of violating for the firm, is compensated by a lower probability of inspection. This confirms the classic results by Becker (1968) and by Polinsky and Shavell (2000) that, in any optimal enforcement scheme, it always makes sense to substitute a higher fine for a lower probability of detection and vice versa. Hence, if the EPA wishes to minimize its enforcement cost, it will set the fine at the largest possible level: $f=\bar{f}$, which would imply that the probability of inspection becomes $q=c / \bar{f}$.

Proposition 1 also provides a possible solution to Harrington's paradox. In equilibrium, the probability of compliance by the firm, $p$, can be high even if the probability of inspection by the environmental agency, $q$, is low.

\subsection{HeTEROGENEOUS ENVIRONMENTAL AGENCIES}

In this and the following sections we consider a strategic model between EPA and DOJ assuming that they may be characterized by different goals, with possibly conflicting objective functions. The firm's objective function is to maximize profits at minimum compliance costs, the EPA's objective function consists of minimizing environmental violations at minimum inspection costs, and the DOJ's objective function is to minimize environmental violations taking into account not only social costs of civil and criminal sanctions (Blondiau and Rousseau 2010) but also 
This is the accepted version of the article published by Springer in Journal of Regulatory Economics. Published version available from: https://doi.org/10.1007/s11149-017-9341-y

Accepted version downloaded from SOAS Research Online: http://eprints.soas.ac.uk/24624/

prestige/popularity/voting/reputational factors related to prosecutors' concerns (Posner 1993; Glaeser et al. 2000; Rasmusen et al. 2009).

This game is divided into two sub-games. The first sub-game (i.e. the baseline model) in which the firm decides whether to comply with environmental regulations or not, and the environmental agency must then decides whether to carry out an inspection or not, without knowing the action of the firm. In the second sub-game, the DOJ is introduced in the model and EPA may initiate civil or criminal judicial enforcement actions. Now, the EPA could serve a notice of violation to the firm and the latter will be referred to DOJ, which can exercise its discretion by deciding whether to initiate a civil or a criminal proceeding. Therefore, EPA's exercise of discretion comes into play in two instances: first with regard to the decision of whether to investigate the violation or not, and then, in the case it does decide to investigate, regarding whether to initiate an administrative, civil or criminal enforcement action. Moreover, if EPA decides to pursue a case civilly, it has two options: it may handle the matter internally or seek fines in a federal court. ${ }^{15}$ If the EPA decides to deal with the case administratively, then it issues a notice of violation (NOV) ordering compliance and/or assigning a penalty to the violation. An NOV describes the violation and commands the violator to stop the activity. ${ }^{16}$ At this point, the firm must again decide whether to be compliant or non-compliant. If it does not comply and if the case cannot be resolved at the administrative level, then the EPA will refer it to the Department of Justice for civil or criminal prosecution. At this stage, the DOJ can exercise its discretion on whether to initiate a civil or a criminal proceeding. ${ }^{17}$ Solving the game by backward induction allows us to see how the enforcement strategy chosen by the DOJ will affect the game between the environmental agency and the firm.

\subsection{The STRATEgIC GAME BETWEen FIRM, EPA AND DOJ}

In Model II we study how the introduction of the DOJ affects the interaction between the firm and EPA, under the assumption that EPA and DOJ could have different objective function. The corresponding game tree is illustrated in Figure 2. We assume also a profit-maximizing firm. In this model if the EPA, after the inspections, finds out that a firm is not compliant with some regulatory prescriptions, it orders the violator to stop the activity (with a notice of violation). If the firm complies, spontaneously or through informal negotiations, then the case ends (on the game tree, the firm chooses to move on the left). If the case cannot be resolved in the administrative process (the firm chooses the strategy on the right), then the EPA will refer it to the DOJ that may proceed against a violator with either a civil suit or a criminal charge. ${ }^{18}$ The DOJ retains exclusive authority to prosecute criminally ${ }^{19}$ and has the authority to initiate all criminal cases

\footnotetext{
15 As noted by Firestone (2003), administrative and civil judicial enforcement share many elements. The primary distinguishing characteristic is that with administrative enforcement, EPA typically functions as both the enforcer and the adjudicator. A judge or EPA, as appropriate, may impose a civil sanction in an environmental matter whenever a person has violated or is violating a law or a permit condition [see, e.g., 42 U.S.C. § 7413(a)(3) (2000)].

${ }^{16}$ The purpose of a NOV is to initiate corrective action that will stop the violation. To provide an incentive for continuing compliance, NOVs for the Clean Water Act may result in monetary penalties up to $\$ 27.500$ per day, per violation, according to 33 U.S.C. $\$ 1319$.

${ }^{17}$ In addition to the imposition of monetary fines and requirements to correct a violation and restore damages, conviction of a criminal environmental violation can result in imprisonment.

${ }^{18}$ The DOJ's charging decision is subject to administrative guidance. Prosecution should proceed only if there is probable cause to believe such a crime has been committed and the evidence is likely to sustain a conviction (2000 United States Attorneys' Manual, at $\S 9-27.200)$. In the decision to proceed the following seven factors are considered: 1) federal law enforcement priorities; 2) the nature and the seriousness of the offense; 3) the deterrent effect of prosecution; 4) the offender's culpability; 5) the offender's criminal history; 6) the offender's willingness to cooperate; and 7) the offender's probable sentence or other consequences of conviction (United States Attorneys' Manual 2000, at § 9-27.200). More specifically, with regard to the decision to prosecute environmental crimes, DOJ guidelines consider the following four factors: 1) voluntary disclosure of a violation or other cooperation with the authorities; 2) the entity's level of
} 
This is the accepted version of the article published by Springer in Journal of Regulatory Economics. Published version available

from: https://doi.org/10.1007/s11149-017-9341-y

Accepted version downloaded from SOAS Research Online: http://eprints.soas.ac.uk/24624/

referred by the EPA. ${ }^{20}$

[FIGURE 2 ABOUT HERE]

The additional notation relative to the model of section 3.1 is as follows. We denote by $c_{1}$ the abatement and clean-up costs to the firm if it complies after being served a notice of violation by EPA, by $c_{2}$ the abatement and clean-up costs imposed by DOJ to the non-compliant firm, by $f_{1}$ the fine from EPA if the firm is compliant after being served with a notice of violation, by $f_{2}$ the fine from DOJ following civil prosecution when the firm chooses to remain non-compliant, by $j$ the criminal sanction imposed, by $k_{c}$ the cost to DOJ of enforcing civil prosecution, by $k_{j}$ the cost to DOJ of enforcing criminal prosecution, and finally by $r$ the reputation cost to DOJ of letting off an offending firm with a fine.

The previous parameters are all positive. In addition, in our discussion we assume that the following parameter restrictions ${ }^{21}$ hold:

(10) $\quad c+c_{1}<c_{2}+j \leq c_{2}+\bar{J}$

(11) $\quad k_{c}<k_{j}$

(12) $f_{2}+k_{j}<r+k_{c}$

Conditions (9)-(12), although not necessary, rule out the possibility of trivial solutions to the strategic game between firm, EPA and DOJ. For instance, condition (9) rules out compliance as a dominant strategy for the firm in the sub-game with the DOJ. If condition (9) does not hold, the firm would always trivially find it optimal to comply irrespective of whether the DOJ implements a civil or a criminal prosecution. Condition (10) rules out that non-compliance may always be a dominant strategy for the firm, irrespective of the DOJ's prosecutorial decision. Similarly to condition (2) for civil prosecution, there must be an upper bound $\bar{j}$ to the largest criminal sentence that can be imposed. Condition (11) rules out that criminal prosecution is always a dominant strategy for DOJ, and condition (12) rules out that civilian prosecution is always a dominant strategy irrespective of the decision of the firm.

The model can be solved by backward induction in two steps. In the first step, the sub-game between the firm and DOJ is solved; in the second step, the outcome of this sub-game is replaced into the game played between the firm and EPA to find their optimal strategies.

\subsection{THE SUB-GAME BETWEEN THE FIRM AND DOJ}

Following the same methodology as before let us consider first the sub-game between the firm and the DOJ. The payoff matrix for this game is shown in Table 2. It is possible to verify that this sub-game has no pure strategy Nash

noncompliance; 3 ) the existence of preventative measures and compliance programs; and 4) whether the entity pursues its own internal disciplinary actions and produces subsequent compliance.

${ }^{19}$ See generally, U.S. Dept. of Justice in cooperation with the National Association of Attorneys, General Guidelines for Joint State/Federal Civil Environmental Enforcement Litigation (2003), available at http://www.naag.org/issues/pdf/envjoint_enf_guidelines-full.pdf

${ }^{20}$ The U.S. DOJ considers all of the following factors in deciding whether to exercise prosecutorial discretion: voluntary, timely, and complete disclosure of the matter under investigation; the degree and timeliness of cooperation; existence and scope of any regularized, intensive, and comprehensive environmental compliance program; pervasiveness of noncompliance; effective internal disciplinary action; and efforts to remedy any on-going non-compliance promptly and completely.

${ }^{21}$ These conditions are highly plausible in practice in the U.S. institutional environmental enforcement system since they correspond to realistic policy options and enforcement procedures that, for several federal environmental laws, can be implemented by both the EPA and the DOJ. 
This is the accepted version of the article published by Springer in Journal of Regulatory Economics. Published version available from: https://doi.org/10.1007/s11149-017-9341-y

Accepted version downloaded from SOAS Research Online: http://eprints.soas.ac.uk/24624/

Equilibrium. For instance, if the DOJ were to resort to civil prosecution, the firm would find it profitable not to comply, since $v-f_{2}-c_{2}>v-c-c_{1}$ by condition (9) above. However, if the firm does not comply, the DOJ would be better off by enforcing a criminal rather than a civil prosecution since $-e+c_{2}-k_{j}>-e+c_{2}+f_{2}-r-k_{c}$ by condition (12).

\section{[TABLE 2 ABOUT HERE]}

The sub-game between the firm and the DOJ does, however, have a mixed strategy Nash Equilibrium. In this equilibrium, the probabilities of compliance by the firm and of enforcing a civil prosecution by DOJ are obtained by requiring that the other player is indifferent between its actions.

The outcome of the sub-game is then replaced into the game played between the firm and EPA in order to compute the mixed strategy Nash Equilibrium of this game.

The expected payoff to DOJ if it enforces a civil prosecution is:

$$
E\left(\pi_{D O J}^{C I}\right)=p_{2}\left(-e+c_{1}-k_{c}\right)+\left(1-p_{2}\right)\left(-e+c_{2}+f_{2}-r-k_{c}\right)
$$

The expected payoff to DOJ if it carries out a criminal prosecution is:

$$
E\left(\pi_{D O J}^{C R}\right)=p_{2}\left(-e+c_{1}-k_{j}\right)+\left(1-p_{2}\right)\left(-e+c_{2}-k_{j}\right)
$$

The firm will choose the probability of compliance, $p_{2}$, in such a way that the DOJ is indifferent between a civil and a criminal prosecution: $E\left(\pi_{D O J}^{C I}\right)=E\left(\pi_{D O J}^{C R}\right)$. Solving for $p_{2}$ yields:

$$
p_{2}=1-\frac{k_{j}-k_{c}}{r-f_{2}}
$$

By condition (11), $k_{j}>k_{c}$ : the cost of criminal prosecution is greater than the cost of civil prosecution. For $p_{2}<1$ we also require that $r>f_{2}$ : the reputation cost to DOJ of letting off an offender with a fine is greater than the benefit from the fine itself.

The expected payoffs to the firm if it complies or does not comply are respectively:

$$
\begin{aligned}
& E\left(\pi_{F}^{2, C}\right)=q_{2}\left(v-c-c_{1}\right)+\left(1-q_{2}\right)\left(v-c-c_{1}\right)=\left(v-c-c_{1}\right) \\
& E\left(\pi_{F}^{2, C}\right)=q_{2}\left(v-f_{2}-c_{2}\right)+\left(1-q_{2}\right)\left(v-c_{2}-j\right)
\end{aligned}
$$

The DOJ will choose the probability of civil prosecution $q_{2}$ in such a way that the firm is indifferent between complying or not: $E\left(\pi_{F}^{2, C}\right)=E\left(\pi_{F}^{2, N C}\right)$. Solving for $q_{2}$ yields:

$$
q_{2}=\frac{j-c-c_{1}+c_{2}}{j-f_{2}}
$$

The numerator on the right-hand side is positive by assumption (10). The denominator is also positive when $j>f_{2}$ : this is a reasonable assumption to make, since it implies that the cost to the firm of a jail sentence is greater than the administrative fine. The above results can be summarized by the following proposition.

Proposition 2. The sub-game played by the firm and DOJ has no pure strategy Nash Equilibrium. There is a mixed strategy Nash Equilibrium which is characterized by the following randomized strategies:

(a) After being referred to the DOJ, the firm complies with probability $p_{2}=1-\left(k_{j}-k_{c}\right) /\left(r-f_{2}\right)$

(b) The DOJ carries out a civil prosecution with probability $q_{2}=\left(j-c-c_{1}+c_{2}\right) /\left(j-f_{2}\right)$

The probability of compliance by the firm is a decreasing function of the cost of criminal prosecution and of the fine $f_{2}$, and is an increasing function of the cost of civil prosecution $k_{c}$ and of the reputation cost $r$ to DOJ. The probability of civil prosecution by DOJ is an increasing function of the fine $f_{2}$, of the criminal sanction $j$ and of the clean-up costs by the firm $c_{2}$, and is a decreasing function of the cost of compliance $c$ and of the abatement pollution costs by the firm $c_{1}$. Also here, we can assume that the DOJ can minimize the probability of enforcing a costly criminal prosecution $\left(1-q_{2}\right)$ by 
This is the accepted version of the article published by Springer in Journal of Regulatory Economics. Published version available

from: https://doi.org/10.1007/s11149-017-9341-y

Accepted version downloaded from SOAS Research Online: http://eprints.soas.ac.uk/24624/

committing itself to imposing the maximum sentence $\bar{\jmath}$, which would imply that the probability of a civil prosecution becomes $q_{2}=\left(\bar{J}-c-c_{1}+c_{2}\right) /\left(\bar{J}-f_{2}\right)$.

Note that, in equilibrium, the expected payoff to the firm from this sub-game is:

$$
E\left(\pi_{F}^{2}\right)=v-c-c_{1}
$$

and the expected payoff to DOJ is:

$$
E\left(\pi_{D O J}\right)=c_{1}-c_{1}\left(\frac{k_{j}-k_{c}}{r-f_{2}}\right)+c_{2}\left(\frac{k_{j}-k_{c}}{r-f_{2}}\right)-k_{j}-e
$$

\subsection{THE GAME BETWEEN THE FIRM AND EPA}

If the firm does not comply in the first stage of the game and is inspected, it is served with a notice of violation by EPA. Note here that, in equilibrium a firm will never comply when the EPA serves a notice of violation because for the firm the non-compliance strategy dominates, since $v-c-c_{1}-f_{1}<v-c-c_{1}$.

The expected payoff to EPA if it serves a notice of violation and if DOJ implements civil prosecution is:

$$
E\left(\pi_{E P A}^{1}\right)=p_{2}\left(-i-e+c_{1}\right)+\left(1-p_{2}\right)\left(-i-e+c_{2}\right)=-i-e+p_{2} c_{1}+\left(1-p_{2}\right) c_{2}
$$

where $p_{2}=1-\left(k_{j}-k_{c}\right) /\left(r-f_{2}\right)$, whence:

$$
E\left(\pi_{E P A}^{2}\right)=-i-e+\left(1-\frac{k_{j}-k_{c}}{r-f_{2}}\right) c_{1}+\left(\frac{k_{j}-k_{c}}{r-f_{2}}\right) c_{2}
$$

The expected payoff to EPA if it serves a notice of violation and DOJ prosecutes criminally is:

$$
E\left(\pi_{E P A}^{2}\right)=p_{2}(0)+\left(1-p_{2}\right)(-e)=e p_{2}-e=-e\left(1-p_{2}\right)
$$

Since we are solving the game by backward induction, we can replace these expected payoffs at the node that initiates the first game between the firm and EPA. The payoff matrix for this game is shown in Table 3.

\section{[TABLE 3 ABOUT HERE]}

Now, the expected payoff to EPA if it carries out an inspection is:

$$
E\left(\pi_{E P A}^{I}\right)=p_{1}(-i)+\left(1-p_{1}\right)\left[-i-e+\left(1-\frac{k_{j}-k_{c}}{r-f_{2}}\right) c_{1}+\left(\frac{k_{j}-k_{c}}{r-f_{2}}\right) c_{2}\right]
$$

and the expected payoff if it does not carry out an inspection is:

$$
E\left(\pi_{E P A}^{N I}\right)=p_{1}(0)+\left(1-p_{1}\right)(-e)=e p_{1}-e=-e\left(1-p_{1}\right)
$$

The firm will choose the probability of compliance, $p_{1}$, in such a way that EPA is indifferent between inspecting or not: $\left(\pi_{E P A}^{I}\right)=E\left(\pi_{E P A}^{N I}\right)$. Solving for $p_{1}$,

$$
p_{1}=\frac{-i+\left(1-\frac{k_{j}-k_{c}}{r-f_{2}}\right) c_{1}+\left(\frac{k_{j}-k_{c}}{r-f_{2}}\right) c_{2}}{\left(1-\frac{k_{j}-k_{c}}{r-f_{2}}\right) c_{1}+\left(\frac{k_{j}-k_{c}}{r-f_{2}}\right) c_{2}}
$$

We can rewrite (26) as follows:

$$
p_{1}=1-\frac{i}{\left(1-\frac{k_{j}-k_{c}}{r-f_{2}}\right) c_{1}+\left(\frac{k_{j}-k_{c}}{r-f_{2}}\right) c_{2}}
$$

The expected payoffs to the firm if it complies and if it does not comply are respectively:

$$
\begin{aligned}
& E\left(\pi_{F}^{1, C}\right)=q_{1}(v-c)+\left(1-q_{1}\right)(v-c)=v-c \\
& E\left(\pi_{F}^{1, N C}\right)=q_{1}\left(v-c-c_{1}\right)+\left(1-q_{1}\right) v=v-q_{1}\left(c+c_{1}\right)
\end{aligned}
$$

The EPA will choose its probability of inspection $q_{1}$ so that the firm is indifferent between complying or not: $E\left(\pi_{F}^{1, C}\right)=$ $E\left(\pi_{F}^{1, N C}\right)$. Solving for $q_{1}$ yields: 
This is the accepted version of the article published by Springer in Journal of Regulatory Economics. Published version available from: https://doi.org/10.1007/s11149-017-9341-y

Accepted version downloaded from SOAS Research Online: http://eprints.soas.ac.uk/24624/

$$
q_{1}=\frac{c}{c+c_{1}}
$$

Note that $0<q_{1}<1$ since $c>0$ and $c_{1}>0$.

In equilibrium, thus, the expected payoff to the EPA is:

$$
E\left(\pi_{E P A)}=-\frac{e i}{c_{1}+\left(\frac{k_{j}-k_{c}}{r-f_{2}}\right)\left(c_{2}-c_{1}\right)}\right.
$$

The above results can be summarized by the following proposition.

Proposition 3. The game played by the firm and EPA has no dominant pure strategy Nash Equilibrium. However, there exists a mixed strategy Nash Equilibrium, which is characterized by the following randomized strategies:

(a) The firm complies with EPA with probability $p_{1}=1-i /\left[\left(1-\frac{k_{j}-k_{c}}{r-f_{2}}\right) c_{1}+\left(\frac{k_{j}-k_{c}}{r-f_{2}}\right) c_{2}\right]$

(b) The EPA carries out an inspection with probability $q_{1}=c /\left(c+c_{1}\right)$

The probability of compliance by the firm is a decreasing function of the cost of inspection, of the reputational costs and of the cost of civil prosecution and is an increasing function of the fine, of the cost of criminal prosecution, and of the clean-up costs if compliant $\left(c_{1}\right)$ and of the clean-up costs when it is not compliant $\left(c_{2}\right)$ and is forced to clean up by DOJ.

In equilibrium, the expected payoff of EPA is a decreasing function of both inspection costs and environmental damages, and is an increasing function of the clean-up cost if compliant $\left(c_{1}\right)$, the clean-up cost when non-compliant $\left(c_{2}\right)$ and the incentive that the DOJ might have to prosecute civilly $\left(k_{j}-k_{c}\right) /\left(r-f_{2}\right)$.

There are some interesting aspects of these results that need to be emphasized. By comparing the EPA's payoffs in the potential different strategies prefigured in the game between the firm, EPA and DOJ, we can observe that the EPA's payoffs, independently of the strategy chosen by DOJ, is $\left(-i-e+c_{1}\right)$ if the firm is compliant, and $\left(-i-e+c_{2}\right)$ if the firm is not compliant.

If $c_{1}=c_{2}$ the EPA is indifferent to the strategy chosen by the firm, but if $c_{2}>c_{1}$ the EPA will be better-off if the firm decides to be non-compliant since the clean-up costs in this case are higher. This implies that, in equilibrium, the EPA will be better-off in expected value of its payoff if the firm decides not to comply. Note also that, if $c_{2}>c_{1}$, the probability of compliance by the firm increases if the incentive the DOJ might have to prosecute civilly $\left(k_{j}-k_{c}\right) /(r-$ $\left.f_{2}\right)$ increases. If $c_{2}>c_{1}$, the incentive for DOJ to prosecute civilly $\left(k_{j}-k_{c}\right) /\left(r-f_{2}\right)$ increases as the cost of criminal prosecution and the fine increase, and as the cost of civil prosecution and the reputational cost decrease. So, if DOJ has a greater incentive to prosecute civilly (because it is less resource intensive), the firm is more likely not to comply, generating higher clean-up costs and making the EPA better-off for this. Since the EPA would have greater incentive to inspect, the firm will try to offset this motivation by increasing its probability of compliance.

All these considerations imply that in equilibrium: a) the DOJ, when the cost of criminal prosecution increases, is more likely to initiate a civil action; b) the EPA would have greater incentive to inspect; and 3) the firm will increase its probability of compliance. In equilibrium, when the EPA is indifferent to the strategy chosen by the DOJ, the firm has an even greater probability of compliance, given that $v-c>v-c-c_{1}$. So, the involvement of DOJ might improve the firm's probability of compliance, strengthening, as a result, the effectiveness of enforcement policies.

\section{THE EXPERIMENTAL DESIGN ${ }^{22}$}

We tested the two game theoretical models under laboratory conditions. We think that this validation could be very

\footnotetext{
${ }^{22}$ Funding for subjects' payments was provided by the University of Rome “Sapienza”, Italy.
} 
This is the accepted version of the article published by Springer in Journal of Regulatory Economics. Published version available from: https://doi.org/10.1007/s11149-017-9341-y

Accepted version downloaded from SOAS Research Online: http://eprints.soas.ac.uk/24624/

fruitful, as experimentation remains a powerful tool for testing and refining theory and for learning about behaviour in carefully controlled environments. The experimental results are, overall, supportive of the view that an environmental approach in which the choice of the enforcement strategy is randomized can be successful in encouraging firms' compliance. Model I is our control treatment, Model II is the heterogeneous treatment. The experiment was conducted at the Law School of the University of Rome "Sapienza"23 (Italy), with subjects being second-year undergraduate students attending Economics classes. The experimental sessions took place in a large classroom and subjects were spaced out so that they could not observe each other's choices. Each subject was provided with a booklet containing the games to be played as well as printed instructions, which were read aloud to all participants. The experiment lasted about 90 minutes

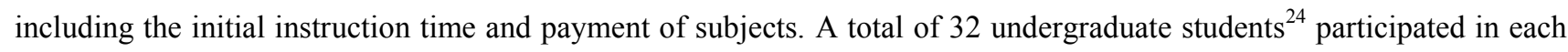
session. None of them had previously participated in economic experiments. Subjects' choices where elicited under hot and cold conditions $^{25}$ and using pairwise choice gambles. This procedure allows for robust results, thus providing a generalization of the theoretical findings to a situation in which agents are not necessarily homogeneous and risk-neutral. Upon completion of the experiment the subjects were asked one by one to approach the experimenter for payment of show up fees and payoffs from the game. Subjects earned on average $€ 25$ including the $€ 5$ show up fee.

In the control treatment, we assigned values to the parameters reported in Figure 1 as follows:

- $\quad$ the probability $q_{1}$ of EPA starting an inspection was set equal to 2/3;

- the value of non-complying firm $v$ was set equal to $€ 50$;

- the cost of compliance $c$ was set equal to $€ 30$;

- $\quad$ the fine $f_{1}$ was set equal to $€ 20$;

- the other two parameters the inspection cost $(-i)$ and the environmental damage $(-e)$ are not relevant to our experiment as they characterize the EPA pay-off which in the experiment is played out by Nature.

In the heterogeneous treatment, we assigned values to the parameters reported in Figure 2 as follows:

- $\quad$ the probability $q_{1}$ of EPA starting an inspection was set equal to $2 / 3$;

- $\quad$ the probability $q_{2}$ of DOJ starting a civil action was set equal to $4 / 5$;

- $\quad$ the value $v$ was set equal to $€ 50$;

- $\quad$ the cost of compliance $c$ was set equal to $€ 30$;

- the additional compliance cost $c_{1}$, if the firm did not comply in the first instance, but did comply after EPA issuing a notice of violation, was set equal to $€ 15$;

- the further abatement and clean up costs to the non-compliant firm, $c_{2}$, was set equal to $€ 16$;

- the fine $f_{1}$, from EPA if the firm is compliant after being served with a notice of violation, was set equal to $€ 20$;

- the fine $f_{2}$ from civil prosecution when the firm chooses to remain non-compliant was set equal to $€ 25$;

- the cost to the firm from criminal prosecution $j$ was set equal to $€ 40$.

Also in this case some parameters where not relevant to our experiment as they characterize the DOJ pay-offs that in the

${ }^{23}$ The experiment was conducted in 2010 .

${ }^{24} 33$ subjects participated when preferences were elicited using pair wise choice lotteries both in the control treatment, and in the heterogeneous treatment.

${ }^{25}$ A hot condition is a situation where subjects' decisions are observe whenever decision nodes are reached. On the contrary, a cold condition is a situation in which all subjects' decisions are observed ahead of reaching decision nodes but are actually played when and if at certain point of the game is actually reached. According to standard game-theoretic view hot and cold methods should yield the same decisions. However, Loewenstein (2005) suggested that a subject could behave differently if his/her decision is elicited under a hot or cold scheme. Roth (1995) presents a short discussion of potentially relevant issues. However, as pointed out in Brandts and Charness (2000) there is no clear consensus among practitioners about it. 
This is the accepted version of the article published by Springer in Journal of Regulatory Economics. Published version available from: https://doi.org/10.1007/s11149-017-9341-y

Accepted version downloaded from SOAS Research Online: http://eprints.soas.ac.uk/24624/

experiment is played out by Nature ${ }^{26}$. In the experimental parameterization, we decided to focus only on the case in which $c_{2}>c_{1}{ }^{27}$ ignoring the other case in which $c_{2}=c_{1}$ (under this circumstance, the EPA is indifferent to the strategy chosen by the firm). As mentioned above, we elicited subjects' behaviour using hot and cold methodologies as well as pairwise choice gambles presented as segmented circles. All the presented risky lotteries were composed of the following outcomes: $-€ 15$, - $€ 6, € 5, € 9, € 20$ and $€ 50$. The probabilities of these outcomes are recorded in Table 4.

\section{[TABLE 4 ABOUT HERE]}

Pairwise choice gamble 1 reported in the first raw of Table 4 represents the firm's choice problem in the control treatment (see Figure 3). If the firm decides to comply (see left gamble), whatever the EPA action is, it will receive $v$-c (set in the experiment equal to $€ 20$ ). If, instead, the firm decides to not comply its payoff depends on the EPA action; it will receive $v-c-c_{1}$ (equal to $€ 5$ ) with probability $q_{1}$ if the EPA decides to inspect, and $v$ (equal to $€ 50$ ) otherwise (see right gamble).

Pairwise choice gamble 2 (Table 4) represents one part of the firm's decision problem developed in the heterogeneous treatment. If the firm decides to comply (see left gamble 2 in Table 4), it receives $v$-c $=€ 20$ whatever the EPA action. If the firm decides to not comply, its pay-off depends on the EPA's action: if the EPA decides to not inspect it receives $v=€ 50$ with probability $1-q_{1}=1 / 3$; if the EPA decides to inspect and the firm reacts to the EPA's notice of violation by complying, then its payoff will be $v-c-c_{1}-f_{1}=-€ 15$ independently of the DOJ decision (see right gamble 2 in Table 4).

Pairwise choice gamble 3 represents another part of game tree depicted in Figure 2. As always, if the firm decides to comply (see the left gamble 3 in Table 4), whatever the EPA action is, it receives $v$-c $=€ 20$; if the firm decides not to comply and the EPA decides not to inspect, the firm receives $v=€ 50$ with probability $1-q_{1}$; if the EPA decides to inspect and the firm does not react to the EPA's notice of violation by complying, then its pay-off depends on the DOJ's strategy. If the firm decides to remain not compliant its payoff is respectively: $v-f_{2}-c_{2}=€ 9$ if the DOJ starts a civil procedure and $v-c_{2}-j=-€ 6$ if the DOJ starts a criminal procedure (see right gamble 3 in Table 4).

Pairwise choice gamble 4 represents another part of the firm's decision problem. If the firm decides to not comply and the EPA decides not to inspect, the firm receives $v=€ 50$ with probability 1- $q_{1}$; if the EPA decides to inspect and the firm reacts to the EPA's notice of violation by complying, then its payoff will be $v-c-c_{1}-f_{1}=-€ 15$ independently of the DOJ decision (see left gamble 4 in Table 4). If, however, the firm decides to comply, after the EPA has referred the case to the DOJ, then its payoff is $v-c-c_{1}=€ 5$, either if DOJ starts a civil procedure or if the DOJ starts a criminal procedure (see right gamble 4 in Table 4).

Pairwise choice gamble 5 represents almost the same decision problem described in pairwise choice gamble 4 , except for the fact that the firm now chooses not to comply even after the EPA has referred the case to DOJ. So, in this case, if the firm decides not to comply and the EPA decides not to inspect, the firm gets $v=€ 50$ with probability $1-q_{1}$; if the EPA decides to inspect and the firm reacts to the EPA's notice of violation by complying, then its payoff will be $v$-c$c_{1}-f_{1}=-€ 15$ independently of the DOJ decision (see left gamble 5 in Table 4). If, however, the firm decides to remain not compliant, after the EPA has referred the case to DOJ, then its two additional payoffs are $v-f_{2}-c_{2}=€ 9$ if DOJ starts a civil

\footnotetext{
${ }^{26} k_{c}$ is the cost to DOJ of enforcing civil prosecution, $k_{j}$ the cost of enforcing criminal prosecution, and finally $r$ is the reputation cost of letting off an offending firm with only a fine

${ }^{27}$ The clean-up costs for the firm when it is not compliant and it is forced to clean up by DOJ $\left(c_{2}\right)$ are greater than the clean-up costs if it is compliant $\left(c_{1}\right)$
} 
This is the accepted version of the article published by Springer in Journal of Regulatory Economics. Published version available from: https://doi.org/10.1007/s11149-017-9341-y

Accepted version downloaded from SOAS Research Online: http://eprints.soas.ac.uk/24624/

procedure and $v-c_{2^{-}} j=-€ 6$ if DOJ starts criminal procedure (see right gamble 5 in Table 4).

Pairwise choice gamble 6 is the last part of the firm's decision problem to be analysed. If the firm decides to not comply and the EPA decides to not inspect, the firm gets, as before, (with probability 1- $q_{1}$ ) $v=€ 50$; if the EPA decides to inspect and the firm reacts to the EPA's notice of violation by not complying, but decides to comply after the case has been referred to DOJ, then its payoff is $v-c-c_{1}=€ 5$ (see left gamble 6 in Table 4) independently of the enforcement action (civil or criminal) chosen by DOJ. If, however, the firm decides to remain non-compliant, after the EPA has referred the case to DOJ, then its payoffs are $v-f_{2}-c_{2}=€ 9$ if DOJ starts a civil procedure and $v-c_{2^{-}} j=-€ 6$ if DOJ starts a criminal procedure (see right gamble 6 in Table 4).

\section{EXPERIMENTAL FINDINGS}

In this section we present the results of our experiment using the hot, the cold and the pairwise choice gamble elicitation methods. As discussed in the experimental design section, we first tested the strategic game between the EPA and the firm. As a preliminary observation, we should remark that 20 out of 32 subjects considered in the hot elicitation method, and 18 out of 32 in the cold elicitation method decided to comply; in the pairwise choice gamble elicitation methods only 12 out of 33 complied (see Table 5). Using a Chi-square test with two degrees of freedom we tested if the compliance rate obtained under the three elicitation methods is the same or not. We cannot reject the null hypothesis at $1 \%$ and $5 \%$ significance levels (we reject it at the $10 \%$ significance level). ${ }^{28}$

\section{[TABLE 5 ABOUT HERE]}

In the heterogeneous treatment we observe that 15 subjects complied with environmental measures in the first move under the hot elicitation method; 18 complied in the cold elicitation method, and 12 in the pairwise choice gamble elicitation methods (see Table 6).

\section{[TABLE 6 ABOUT HERE]}

Tests of whether subjects' compliance rate in the first node change across elicitation methods cannot reject the null hypothesis (at any significance level). In the second decision node all subjects that received a notice of violation from the EPA decided to not comply irrespective of the elicitation method. In the third decision node (i.e. once the EPA refers to the DOJ) we can observe that, in the hot elicitation method, $38 \%$ of subjects that initially decided to remain noncompliant switched to a compliant behaviour once the EPA notifies the violation; this percentage rise to $75 \%$ in the cold elicitation method $^{29}$ and up to $79 \%$ in the pairwise choice gamble elicitation methods. Using again a Chi-square test with two degrees of freedom we tested if the compliance rate obtained under the three elicitation methods is the same or not. We cannot reject the null hypothesis at a significance level of $2.5 \%$. This finding is driven by the result obtained when eliciting subject behaviours with hot method, which differs significantly form the results obtained under the other two elicitation methods. In fact, by testing hot vs. cold, we can reject the null hypothesis at the 5\% significance level; by

\footnotetext{
${ }^{28}$ Testing hot $v s$. cold we cannot reject the null hypothesis at any significance level; testing hot (cold) vs. pairwise choice gamble we reject the null hypothesis at a 5\% (11\%) significance level.

${ }^{29}$ Note that, although in the experiment instructions it was clearly stated that subjects should have made a decision every time they reached a node followed by dotted lines, only 16 subjects (out of 32) expressed their choices on the whole game tree.
} 
This is the accepted version of the article published by Springer in Journal of Regulatory Economics. Published version available from: https://doi.org/10.1007/s11149-017-9341-y

Accepted version downloaded from SOAS Research Online: http://eprints.soas.ac.uk/24624/

testing hot vs. pairwise choice gamble, we can reject the null hypothesis at the $1 \%$ significance level; however, by testing cold vs. pairwise choice gamble, we cannot reject the null hypothesis at any significance level. We can now state our first experimental result:

\section{RESULT 1: Subjects' behaviour is largely unaffected by the used elicitation method.}

Now we compare the compliance rate in the control treatment with the first move compliance rate in the heterogeneous treatment. We tested subjects' behaviour for the three elicitation methods pooling all the data together, and separately. We cannot reject the null hypothesis that the behaviour is the same in all the elicitation methods at any significance level. This yields our second result:

RESULT 2: The introduction of the DOJ does not produce, in the first move, a reduction of the compliance rate.

As we already stated in the second movement (irrespective of the elicitation methods) all the subjects that received a notice of violation from the EPA continue to be non-compliant; they are respectively 13, 16, and 26 in hot, cold, and pairwise choice. Then - once the EPA refers to the DOJ - 5 subjects out of 13 in the hot, 12 subjects out of 16 in the cold, and 26 subjects out of 33 in the pairwise choice decided to comply. We can affirm, therefore, that in qualitative terms there are no divergences among the different elicitation methods since, once the EPA has referred the case to the DOJ for civil or criminal prosecution, the firm's probability of compliance might improve; this is consistent with one of the main results of the theoretical model.

As set in the model, we know that the probability of inspection (and hence, for those firms who did not comply, the probability of receiving a notice of violation) is $q_{1}=c /\left(c+c_{1}\right)$. So, under our experimental parameterization, this probability will be equal to $2 / 3$. Therefore, we can expect that out of the 17 firms that did not comply, in the first instance, only 11.3 will be inspected by the EPA and, then, only 4.3 will switch to compliance. All in all, this adds up to $15+4.3=$ 19.3 complying firms in the hot elicitation method. In the cold elicitation method we observe 14 firms that did not comply, in the first instance, 9.3 of which will be inspected and so we can expect that out of the inspected firms 7 will comply; this adds up to $18+7=25$ complying firms in the cold elicitation method. In the pairwise choice elicitation method we observe 21 firms that did not comply in the first move, consequently only 14 will be inspected and out of the inspected firm 11.03 will comply; all in all, in the pairwise choice gamble elicitation methods we will end up with $12+11.03=23.03$ complying firms. On the one hand, comparing the compliance overall rate under the three elicitation methods we cannot reject the null hypothesis that they are equal, and this reinforces our Result 1 . On the other hand, pooling all the data from the three elicitation methods and comparing the overall compliance rates in the two treatments (i.e. control and heterogeneous) we reject the null hypothesis of equality at a $2.5 \%$ significance level. We can now state our third result.

RESULT 3: Introducing criminal enforcement generates a statistically significant increase in the number of compliant subjects.

These results can bring new evidence in the experimental literature on enforcement issues contributing to a better understanding of how firms' compliance choices respond to the different enforcement approaches in a novel and realistic theoretical framework in which the use of administrative and criminal environmental enforcement approaches are combined together.

\section{Conclusions}

During the last few decades, the enforcement toolbox of U.S. environmental regulators and institutions has been severely criticized (Abbot 2005) for leaving too large an amount of discretion, administrative and/or investigative, in the hands of the Environmental Protection Agency, and prosecutorial in the hands of the Department of Justice. The U.S. 
This is the accepted version of the article published by Springer in Journal of Regulatory Economics. Published version available from: https://doi.org/10.1007/s11149-017-9341-y

Accepted version downloaded from SOAS Research Online: http://eprints.soas.ac.uk/24624/

EPA has been promoting enforcement activities on all fronts but especially on criminal actions ${ }^{30}$. Such a trend has come under criticism as it has been argued that the fear of being indicted may, in the long run, undermine environmental compliance thereby worsening both the relations between EPA and firms and environmental conditions (Coffee 1991; Green 1997; Gaynor and Lippard 2002). Moreover, as noted by Firestone (2003), the decision about whether to enforce and what kind of enforcement action to undertake rests entirely in the discretion of the enforcer. This discretion implies that, rightly or wrongly, some cases are handled administratively, whereas very similar cases end up in the courts (Babbit Cory, et al. 2004). In some circumstances civil injunctions are issued to prevent further harm and to begin clean-up procedures, while in some others, criminal sanctions are applied to further punish the violator. ${ }^{31}$

The design of monitoring and enforcement policy is of great importance to policy makers not only because it influences the impacts of environmental legislation but also because it involves substantial public expenditures (Rousseau 2007). We do believe that the analysis developed in this paper can offer important insights into the regulator's behaviour. When the cost of criminal prosecution increases, in equilibrium: a) the DOJ is more likely to initiate a civil action; b) the EPA would have greater incentive to inspect; and 3) the firm will increase its probability of compliance. Overall, our theoretical results may be somewhat surprising since they run counter to the general consensus in the literature that a consistent and predictable enforcement is preferable: we suggest, by contrast, that a discretionary enforcement strategy may generate higher compliance. Another crucial implication of our results is that EPA and DOJ may engage in a strategic interaction in their environmental enforcement behaviour. We show that not only do they influence each other in their enforcement decisions, but they also impact on decisions by the firms and increase their probability of compliance. Our results go in the same direction and strengthen, to some extent, the analysis by Billiet (2012) that has shed light on the fact that in Europe there is an emerging move towards combined criminal-administrative enforcement systems. In fact, while the more recent EU official policy encourages the use of criminal enforcement and aims at strengthening enforcement systems that rely strongly on administrative enforcement (European Commission 2008), several European countries that predominantly relied on criminal enforcement in the past (i.e., Belgium and UK) recently moved towards more administrative enforcement (Svatikova 2012). We suggest that increasing the scope of criminal enforcement programmes would possibly strengthen deterrence not only because criminal sanctions might improve the effectiveness of enforcement policies but also because, the Department of Justice in the interplay with the EPA, would generate for the latter a greater incentive to carry out inspections and punish the violator, increasing, thus, the probability of compliance of potential offenders. This result is particularly relevant considering that both in the United States and in the European Union environmental regulators have, in the last decade, been actively reviewing how to extend criminal sanctions in terms of their scale and scope to enhance deterrence (U.S. Senate 2003; House of Commons 2005; European Commission 2008).

Our experimental results provide, moreover, a strong empirical validation of the theoretical outcomes obtained in the game theory model by supporting the argument that criminal enforcement can enhance deterrence by improving firms' compliance. In terms of environmental policy implications, our result can have notable policy implications concerning the optimal choice of enforcement strategies by suggesting that, even though EPA and DOJ have to work together for a better environmental quality, they do not need to share the same objective functions to maximize the level

\footnotetext{
${ }^{30}$ U.S. EPA, Compliance and Enforcement Annual Results (various years).

${ }^{31}$ The application of civil sanctions, generally, includes fines, negative publicity and installation of pollution-control technology, while the application of criminal sanctions includes also fine and imprisonment. The main distinction between sanctions in the criminal and civil systems is the availability of criminal non-monetary sanctions, such as incarceration and probation.
} 
This is the accepted version of the article published by Springer in Journal of Regulatory Economics. Published version available from: https://doi.org/10.1007/s11149-017-9341-y

Accepted version downloaded from SOAS Research Online: http://eprints.soas.ac.uk/24624/

of compliance by the firms. While motivated by and intended to analyze the enforcement of environmental regulations based on the conventional enforcement system mostly applied in the U.S, the game theoretic models developed here are likely to be applicable in a variety of other contexts that entail relationships between competing and/or independent enforcement institutions. They can be applied to analyze enforcement options and players' behavior in, for instance, financial crime areas, such as tax law enforcement, money laundering, etc. One possible way to extend this study for future research could be to develop dynamic game theory models where players can learn how to play over time and can update their beliefs by learning from their past experiences and acquired knowledge of the other players' actions and their payoffs.

\section{REFERENCES}

Abbot, C. (2005). The Regulatory Enforcement of Pollution Control Laws. Journal of Environmental Law, 17(2), 161180.

Abbot, C. (2009). Enforcing Pollution Control Regulation - Strengthening Sanctions and Improving Deterrence. Hart: London.

Anderson, L.R., S.L., Stafford (2003). Punishment in a Regulatory Setting: Experimental Evidence from the VCM. Journal of Regulatory Economics, 24(1), 91-110.

Ayres, I., and J. Braithwaite (1992). Responsive regulation: Transcending the deregulation debate. Oxford: Oxford University Press.

Babbit, C.J., D.C., Cory, B.L., Kruchek (2004). Discretion and the Criminalization of Environmental Law. Duke Environmental Law and Policy Forum, 15(1).

Baker, T., A., Harel, T., Kugler (2004). The Virtues of Uncertainty in Law: An Experimental Approach. Iowa Law Review, 89, 443-494.

Barker, D.A. (2002). Environmental Crimes, Prosecutorial Discretion, and the Civil/Criminal Line. Virginia Law Review. $88,1387$.

Becker, G.S. (1968). Crime and Punishment: an Economic Approach. Journal of Political Economy, 76, 69-217.

Becker, G., and G. Stigle (1974). Law enforcement, malfeasance, and compensation of enforcers. Journal of Legal Studies, 3(1), 1-18.

Billiet, C. M. (2012). Satellite images as evidence for environmental crime in Europe. A judges perspective. In R. Purdy and D. Leung (Ed.), Evidence from earth observation satellites. Emerging legal issues. Leiden - Boston, Brill.

Blondiau, T., C.M. Billiet and S. Rousseau (2015). Comparison of criminal and administrative penalties for environmental offenses. European Journal of Law and Economics, 39(1), 11-35.

Blondiau, T., S., Rousseau (2010). The impact of the judicial objective function on the enforcement of environmental standards. Journal of Regulatory Economics, vol. 37 (2), 196:214.

Bowles R., M. G Faure and N. Garoupa (2008). The Scope of Criminal Law and Criminal Sanctions: An Economic View and Policy Implications. Journal of Law and Society, 35:389.

Brandts, J., G. Charness (2000). Hot vs. cold: Sequential responses and preference stability in experimental games. Experimental Economics, 2(3), 227-238.

Clifford, R. (2007). Shining the Spotlight on European Union Environmental Compliance. Pace Environmental Law Review, 24 (1), http://digitalcommons.pace.edu/pelr/vol24/iss 1/7

Coffee, J.C. (1991). Does Unlawful mean Criminal?: Reflections on the Disappearing Tort/Crime Distinction in American Law. Boston University Law Review, 193.

Cohen, M. (1999). Monitoring and Enforcement of Environmental Policy, in Tietenberg, T. and Folmer. H. (eds.). International Yearbook of Environmental and Resource Economics 1999/2000, vol. III, Edward Elgar Publishers, Northampton, Massachussets, 44-106.

Cohen, M. (2000). Empirical Research on the Deterrent Effect of Environmental Monitoring and Enforcement. Environmental Law Report, 30.

Cory, C.D., A.R., Germani (2002). Criminal Sanction for Agricultural Violations of the CWA. Water Policy, 4(6).

Dasgupta, S., H., Hettig, D., Wheeler (2000). What Improves Compliance? Evidence from Mexican Industry. Journal of Environmental Economics and Management, 39, 39-66.

Deily, M.E., W.B., Gray (2007). Agency Structure and Firm Culture: OSHA, EPA, and the Steel Industry. The Journal of Law, Economics \& Organization, vol. 23(3), 685-709.

DiMento, J.F. (1993). Enforcement of Environmental Law. Annals of the American Academy of Political and Social Science, vol. 525, 134-146. 
This is the accepted version of the article published by Springer in Journal of Regulatory Economics. Published version available

from: https://doi.org/10.1007/s11149-017-9341-y

Accepted version downloaded from SOAS Research Online: http://eprints.soas.ac.uk/24624/

Dion, C., P., Lanoie, B., Laplante (1998). Monitoring of Pollution Regulation: do Local Conditions Matter?. Journal of Regulatory Economics, 13(1), 5-18.

EPA (2016). Enforcement Annual Results Numbers at a Glance for Fiscal Year 2016. https://www.epa.gov/enforcement/enforcement-annual-results-numbers-glance-fiscal-year-2016

Esworthy, R. (2014). Federal Pollution Control Laws: How Are They Enforced? Congressional Research Service (CSR) Report, 7-5700. https://fas.org/sgp/crs/misc/RL34384.pdf

European Commission (2008). Directive 2008/99/EC on the protection of the environment through criminal law. http://ec.europa.eu/environment/legal/crime/index.htm.

Faure, M.G., J.S., Johnston (2008). The Law and Economics of Environmental Federalism: Europe and the United States Compared. Faculty Scholarship Paper 202, http://scholarship.law.upenn.edu/faculty scholarship/202

Faure, M.G., A. Ogus and N. Philipsen (2009). Curbing Consumer Financial Losses: The Economics of Regulatory Enforcement. Law \& Policy, 31:161.

Faure, M.G. and K. Svatikova (2012). Criminal or Administrative Law to Protect the Environment? Evidence from Western Europe. Journal of Environmental Law, 24(2):253-286.

Firestone, J. (2003). Enforcement of Pollution Laws and Regulations: an Analysis of Forum Choice. Harvard Environmental Law Review, 27, 105-176.

Friesen, L. (2003). Targeting Enforcement to Improve Compliance with Environmental Regulations. Journal of Environmental Economics and Management, 46, 72-85.

Franckx, L. (2001a). Ambient Environmental Inspections in Repeated Enforcement Games, Working Paper Series n. 2001-12, Katholieke Universiteit Leuven, http://feb.kuleuven.be/drc/Economics/misc/ete_workingpapers/ete-wp0112.pdf

Franckx, L. (2001b). Ambient Environmental Monitoring, Sequential Firm Inspections and Time-Decreasing Benefits of Inspection. Economic Bullettin, 17(1).

Franckx, L. (2002). The use of ambient inspections in environmental monitoring and enforcement when the inspection agency cannot commit itself to announced inspection probabilities. Journal of Environmental Economics and Management, 43(1), 71-92.

Frase, R.S. (1980), The Decision to File Federal Criminal Charges: A Quantitative Study of Prosecutorial Discretion. University of Chicago Law Review, 47:246-303.

Hampton, P. (2005). Reducing administrative burdens: Effective inspection and enforcement. Retrieved: http://www.bis.gov.uk/files/file44593.pdf

Harsanyi, J.C. (1973). Games with randomly disturbed payoffs: a new rationale for mixed-strategy equilibrium payoffs. International Journal of Game Theory, 2, 1-23.

Gaynor, K.A., B.S., Lippard (2002). Environmental Enforcement: Industry should not be Complacent. Environmental Law Reporter, 32.

Glaeser, E., D., Kessler, A., Piehl (2000). What Do Prosecutors Maximize? An Analysis of the Federalization of Drug Crimes. American Law and Economics Review, 2, 259-290.

Glicksman, R., D., Earnhardt (2007). Depiction of the Regulator-Regulated Entity Relationship in the Chemical Industry: Deterrence-Based v. Cooperative Enforcement. William and Mary Environmental Law and Policy Review, 31(3).

Gray, W.B., J.P., Shimshack (2011). The effectiveness of environmental monitoring and enforcement: a review of the empirical evidence. Review of Environmental Economics and Policy, 5, 3-24.

Green, S.P. (1997). Why it's a Crime to Tear the Tag Off a Mattress: Overcriminalization and the Moral Content of Regulatory Offenses. Emory Law Journal, 46, 1533-1615.

Harrington, W. (1988). Enforcement Leverage when Penalties are Restricted. Journal of Public Economics, $37,29-53$.

Harsanyi, J.C. (1973). Games with randomly disturbed payoffs: a new rationale for mixed-strategy equilibrium payoffs. International Journal of Game Theory, 2, 1-23.

Helland, E. (1998). The Enforcement of Pollution Control Laws: Inspections, Violations and Self-Reporting. Review of Economics and Statistics, 80, 141-153.

Hertz M. (2011). Structures of Environmental Criminal Enforcement. Fordham Environmental Law Review, 7(3):678718.

Heyes, A. (2000). Implementing environmental regulation: enforcement and compliance, Journal of Regulatory Economics, 17, 107-129.

Heyes, A., N., Rickman (1999). Regulatory Dealing - Revisiting the Harrington Paradox. Journal of Public Economics, 72, 361-378.

Heyes, A. (1998). Making Things Stick: Enforcement and Compliance. Oxford Review of Economic Policy, 14 (4), $50-63$.

House of Commons (2005). Government Response to the Committee's Second Report of Session 2004-05 on Corporate Environmental Crime, available at: http://www.parliament.the-stationery-office.com.

Kane, P.S. (1993). Why have you singled me out? The use of prosecutorial discretion for selective prosecution. Tulane Law Review, 67, 2293.

Kleven, H. J., M., Knudsen, C.T., Kreiner, S., Pedersen, E., Saez, E. (2011). Unwilling or Unable to Cheat? Evidence from a Tax Audit Experiment in Denmark. Econometrica 79(3), 651-692. 
This is the accepted version of the article published by Springer in Journal of Regulatory Economics. Published version available

from: https://doi.org/10.1007/s11149-017-9341-y

Accepted version downloaded from SOAS Research Online: http://eprints.soas.ac.uk/24624/

Krämer, L. (2002). Thirty Years of EC Environmental Law: Perspectives and Prospectives. Yearbook of European Environmental Law, vol. 2.

Holler, M.J. (1993). Fighting Pollution When Decisions are Strategic. Public Choice, 76, 347-356.

Jones, C.A., S., Scotchmer (1990). The Social Cost of Uniform Regulatory Standards in a Hierarchical Government. Journal of Environmental Economics and Management, 19, 61-72.

Lando, H., S., Shavell (2004). The Advantage of Focusing Law Enforcement Effort. International Review of Law and Economics, 24, 209-218.

Laplante, B., P., Rilstone (1996). Environmental Inspections and Emissions of the Pulp and Paper Industry in Quebec. Journal of Environmental Economics and Management, 31, 19-36.

Linder, S. H., M.E. McBride (1984). Enforcement costs and regulatory reform: The agency and firm response. Journal of Environmental Economics and Management, 11(4):327.

Loewenstein, G. (2005). Hot-Cold Empathy Gaps and Medical Decision-Making. Health Psychology, 24, S49-S56, 1366-1377.

Macrory, R. (2006). Regulatory justice: Making sanctions effective. Retrieved: http:/www.bis.gov.uk/ files/file44593.pdf

Magat, W.A., W.K., Viscusi (1990). Effectiveness of the EPA's Regulatory Enforcements: The Case of Industrial Effluent Standards. Journal of Law and Economics, 30, 331-360.

Michael, D. (1992). To Make the Punishment Fit the Crime: Essays in the Theory of Criminal Justice, Boulder, CO: Westview.

Mintz, J.A. (2012). Enforcement at the EPA: high stakes and hard choices. Austin, TX: University of Texas Press. Revised ed.

Morris, S. (2008). Purification, in The New Palgrave Dictionary of Economics, $2^{\text {nd }}$ ed., eds. Durlauf, S.N., and L.E., Blume, Palgrave Macmillan.

Niskanen, W. A. (1975). Politicians and Bureaucrats. Journal of Law and Economics, 18, 617-43.

Ogus A. (2004). Enforcing Regulation: Do We Need the Criminal Law?' in H. Sjogren and G. Skogh (eds). New Perspectives on Economic Crime, Cheltenham, UK - Northampton, MA, USA, Edward Elgar.

Ogus A. and C. Abbot (2002). Sanctions for Pollution: Do We Have the Right Regime?. Journal of Environmental Law, 14:283.

Ordershook, P. (1986). Game Theory and Political Theory. NY: Cambridge University Press.

Peltzman, S. (1976). Toward a More General Theory of Regulation. Journal of Law and Economics, 19, 211-40.

Polinsky, A.M., S., Shavell (2000). The Economic Theory of Public Enforcement of Law. Journal of Economic Literature, 38, 45-74.

Polinsky, A.M., S., Shavell (2006). The theory of public enforcement of law. Elsevier, Amstersdam.

Posner, R. (1993). What do Judges and Justices Maximize? (The same Thing Everybody Else Does), Supreme Court Economic Review, vol.3.

Rasmusen, E. (1996). Stigma and self-fulfilling expectations of criminality. Journal of Law and Economics, 39, 519-544.

Rasmusen, E., M., Raghav, M., Ramseyer (2009). Convictions Versus Conviction Rates: The Prosecutor's Choice. American Law and Economics Review, 11(47).

Reinganum, J.F., L.L., Wilde (1986). Equilibrium verification and reporting policies in a model of tax compliance. International Economic Review, 27(3), 739-760.

Rousseau, S. (2007). The Impact of Sanctions and Inspections on Firms' Environmental Compliance Decisions. Energy, Transport and Environment. Katholieke Universiteit Leuven, working paper series, n. 4.

Roth, A. (1995). Bargaining Experiments. In Handbook of Experimental Economics, J. Kagel and A. Roth, eds., 1995, pp. 253-348.

Shavell, S. (1993). The optimal structure of law enforcement. Journal of Law and Economics, 36(1), $255-287$.

Shimshack, J.P. (2014). The Economics of Environmental Monitoring and Enforcement. Annual Review of Resource Economics, 6, 339-360.

Shimshack, J.P., M. B., Ward (2005). Regulator Reputation, Enforcement, and Environmental Compliance. Journal of Environmental Economics and Management, 50, 519-540.

Scholz, J.T. (1991). Cooperative Regulatory Enforcement and the Politics of Administrative Effectiveness. American Political Science Review, 85, 115-136

Stafford, S.L. (2002). The Effect of Punishment on Firm Compliance with Hazardous Waste Regulations. Journal of Environmental Economics and Management, 44, 290-308.

Stafford, S.L. (2003). Assessing the Effectiveness of State Regulation and Enforcement of Hazardous Waste. Journal of Regulatory Economics, 23, 27-41.

Stigler, G.J. (1971). The Theory of Economic Regulation. The Bell Journal of Economics and Management Science, 2, 321.

Stranlund, J. (2013). A brief review of the economics of enforcing environmental policies. Encyclopedia of Energy, Natural Resource, and Environmental Economics, Newnes.

Sunstein, C.R., D., Kahneman, D., Schkade, I., Ritov (2002). Predictably incoherent judgments. Stanford Law Review, 54, $1153-1215$. 
This is the accepted version of the article published by Springer in Journal of Regulatory Economics. Published version available from: https://doi.org/10.1007/s11149-017-9341-y

Accepted version downloaded from SOAS Research Online: http://eprints.soas.ac.uk/24624/

Svatikova, K. (2012). Criminal or administrative law to protect the environment? Evidence from Western Europe. Journal of Environmental Law, 24(2), 253-286.

Svatikova, K. (2011). Complementary use of administrative and criminal fines in enforcing environmental regulations. PhD Thesis: Economic criteria for criminalization: Optimizing enforcement in case of environmental violations, Chapter 6.

Tosun, J. (2012). Environmental Monitoring and Enforcement in Europe: a Review of Empirical Research. Environmental Policy and Governance, 22, 437-448.

Tsebelis, G. (1989). The Abuse of Probability in Political Analysis: The Robinson Crusoe Fallacy. The American Political Science Review, 83, 77-91.

United Nations Environment Programme (2006). Manual on Compliance with and Enforcement of Multilateral Environmental Agreements. Nairobi, UNEP.

U.S. EPA. Compliance and Enforcement Annual Results, various years.

U.S. Senate (2003). Criminal and Civil Enforcement of Environmental Laws: Do We Have all the Tools We Need? Hearing. U.S. Governmental Printing 107.97.

Viscusi, W.K., R.J., Zeckhauser (1979). Optimal Standards with Incomplete Enforcement. Public Policy, 27, $437-56$.

Yeager, P. (1991). The Limits Of Law: The Public Regulation of Private Pollution. Cambridge University Press. 
This is the accepted version of the article published by Springer in Journal of Regulatory Economics. Published version available from: https://doi.org/10.1007/s11149-017-9341-y

Accepted version downloaded from SOAS Research Online: http://eprints.soas.ac.uk/24624/

Table 1. Payoff matrix for the strategic game between firm and EPA

\begin{tabular}{|c|c|c|}
\hline & \multicolumn{2}{|c|}{ EPA } \\
\hline & Inspect & $\begin{array}{l}\text { Do not } \\
\text { inspect }\end{array}$ \\
\hline $\begin{array}{l}\text { Comply } \\
\text { Firm }\end{array}$ & $(v-c,-i)$ & $(v-c, 0)$ \\
\hline $\begin{array}{l}\text { Do not } \\
\text { comply }\end{array}$ & $(v-f,-i-e+f)$ & $(v,-e)$ \\
\hline
\end{tabular}


This is the accepted version of the article published by Springer in Journal of Regulatory Economics. Published version available from: https://doi.org/10.1007/s11149-017-9341-y

Accepted version downloaded from SOAS Research Online: http://eprints.soas.ac.uk/24624/

Table 2. Payoff matrix for the sub-game between firm and DOJ

DOJ
Civil
Criminal

\begin{tabular}{|c|c|c|c|c|}
\hline \multirow{3}{*}{ Firm } & Comply & $\left(v-c-c_{1},-e+c_{1}-k_{c}\right)$ & $\left(v-c-c_{1},-e+c_{1}-k_{j}\right)$ & \multirow{3}{*}{$\left(1-p_{2}\right)$} \\
\hline & Do not & $\left(v-f_{2}-c_{2}\right.$ & $\left(v-c_{2}-j,-e+c_{2}-k_{j}\right)$ & \\
\hline & comply & $\left.-e+c_{2}+f_{2}-r-k_{c}\right)$ & & \\
\hline
\end{tabular}


This is the accepted version of the article published by Springer in Journal of Regulatory Economics. Published version available from: https://doi.org/10.1007/s11149-017-9341-y

Accepted version downloaded from SOAS Research Online: http://eprints.soas.ac.uk/24624/

Table 3. Payoff matrix for the game between firm and EPA in the first-stage game

EPA

Inspect Do not

inspect

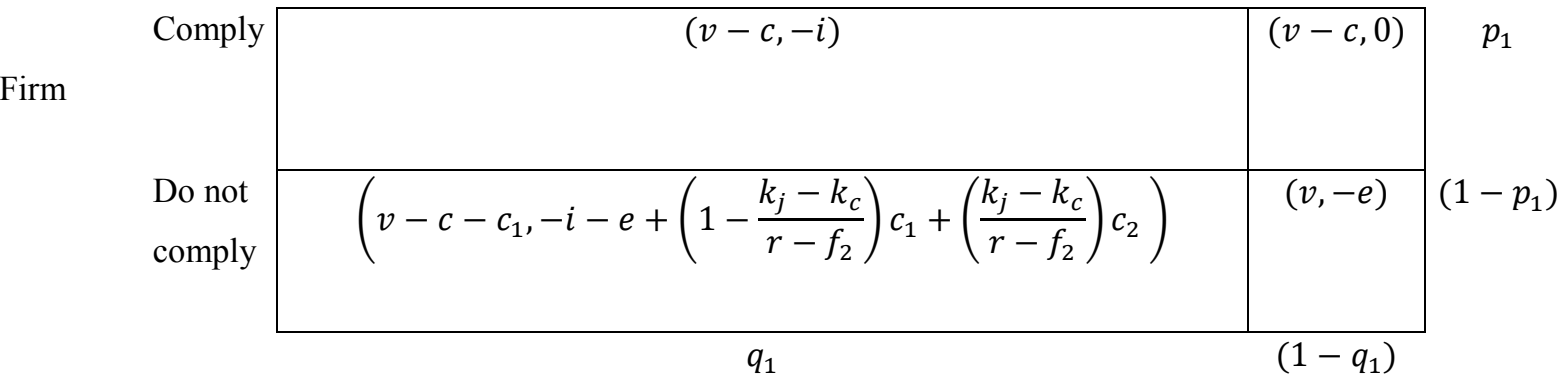


This is the accepted version of the article published by Springer in Journal of Regulatory Economics. Published version available from: https://doi.org/10.1007/s11149-017-9341-y

Accepted version downloaded from SOAS Research Online: http://eprints.soas.ac.uk/24624/

Table 4. Gambles of all games - summary table (second experiment)

\begin{tabular}{|c|c|c|c|c|c|c|c|c|c|c|c|c|c|}
\hline \multicolumn{14}{|c|}{$\begin{array}{l}\text { Pairwise choice } \\
\text { gambles }\end{array}$} \\
\hline & $\epsilon$ & -15 & -6 & 5 & 9 & 20 & 50 & -15 & -6 & 5 & 9 & 20 & 50 \\
\hline Gamble 1 & & 0 & 0 & 0 & 0 & 1 & 0 & 0 & 0 & 0.66 & 0 & 0 & 0.33 \\
\hline Gamble 2 & & 0 & 0 & 0 & 0 & 1 & 0 & 0.66 & 0 & 0 & 0 & 0 & 0.33 \\
\hline Gamble 3 & & 0 & 0 & 0 & 0 & 1 & 0 & 0 & 0.18 & 0 & 0.49 & 0 & 0.33 \\
\hline Gamble 4 & & 0.66 & 0 & 0 & 0 & 0 & 0.33 & 0 & 0 & 0.66 & 0 & 0 & 0.33 \\
\hline Gamble 5 & & 0.66 & 0 & 0 & 0 & 0 & 0.33 & 0 & 0.18 & 0 & 0.49 & 0 & 0.33 \\
\hline Gamble 6 & & 0 & 0 & 0.66 & 0 & 0 & 0.33 & 0 & 0.18 & 0 & 0.49 & 0 & 0.25 \\
\hline
\end{tabular}

Table 5. Compliance rate in the strategic game between firm and EPA

\begin{tabular}{cc}
\hline Treatment & Compliance rate \\
\hline Hot & 0.6250 \\
Cold & 0.5625 \\
Lotteries & 0.3750 \\
\hline \hline
\end{tabular}

Table 6. Compliance rate in the strategic game among firm, EPA and DOJ

\begin{tabular}{cccc}
\hline \multirow{2}{*}{ Treatment } & First node & $\begin{array}{c}\text { Compliance rate } \\
\text { Second node }\end{array}$ & Third node \\
\hline Hot & 0.4687 & 0 & 0.3846 \\
Cold & 0.5625 & 0 & 0.7500 \\
Lotteries & 0.3636 & 0 & 0.7879 \\
\hline \hline
\end{tabular}


This is the accepted version of the article published by Springer in Journal of Regulatory Economics. Published version available from: https://doi.org/10.1007/s11149-017-9341-y

Accepted version downloaded from SOAS Research Online: http://eprints.soas.ac.uk/24624/

Figure 1. Strategic game between the firm and the EPA in extensive form

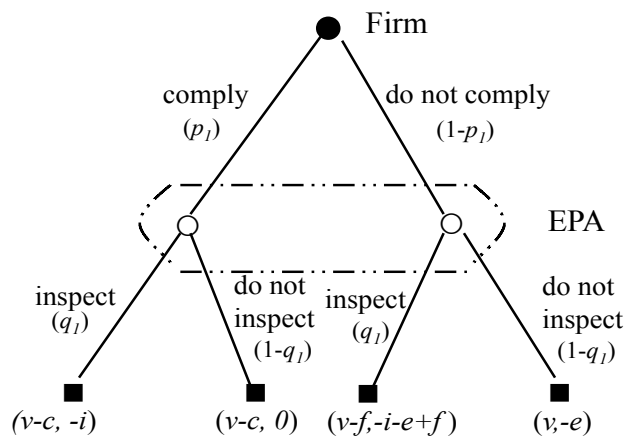


This is the accepted version of the article published by Springer in Journal of Regulatory Economics. Published version available from: https://doi.org/10.1007/s11149-017-9341-y

Accepted version downloaded from SOAS Research Online: http://eprints.soas.ac.uk/24624/

Figure 2. Strategic game between firm, EPA and DOJ in extensive form

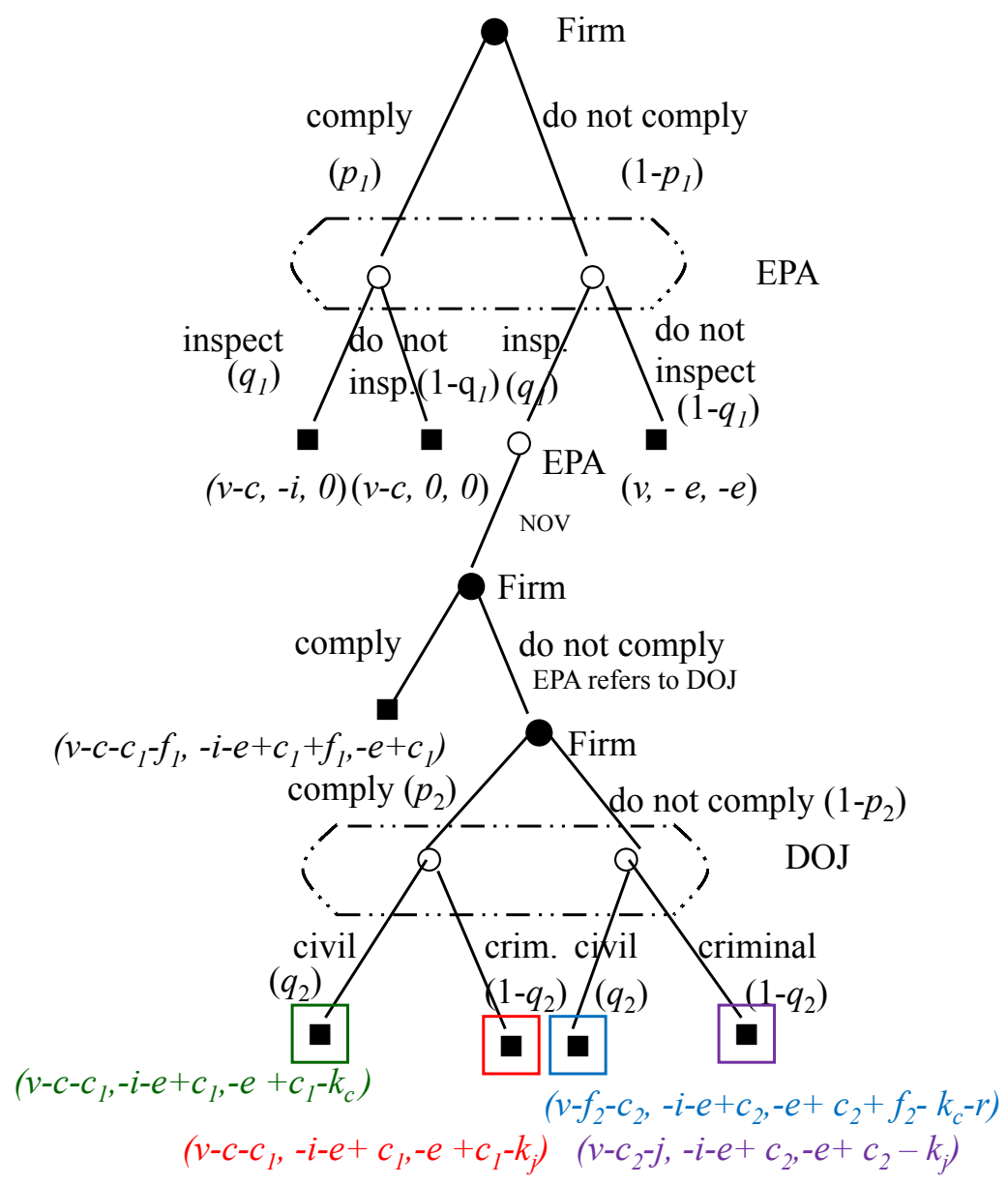


This is the accepted version of the article published by Springer in Journal of Regulatory Economics. Published version available from: https://doi.org/10.1007/s11149-017-9341-y

Accepted version downloaded from SOAS Research Online: http://eprints.soas.ac.uk/24624/

Figure 3. Gambles of the game between firm and EPA

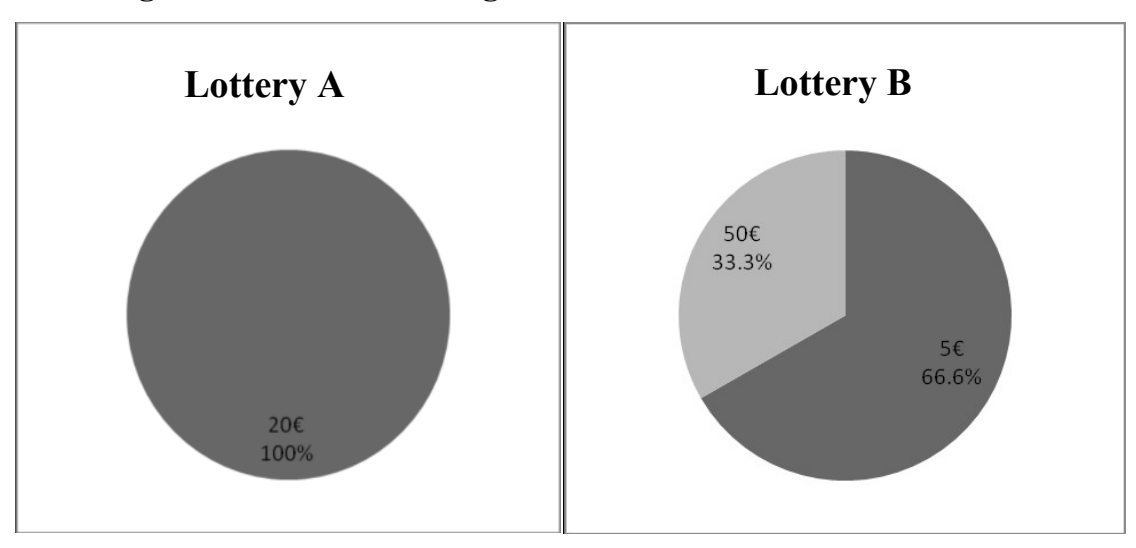

